\title{
Influence of soil tillage system on soil compaction and winter wheat yield
}

\author{
Milan Biberdzic ${ }^{1 *}$, Sasa Barac ${ }^{1}$, Dragana Lalevic ${ }^{1}$, Aleksandar Djikic ${ }^{1}$, Danijela Prodanovic ${ }^{1}$, \\ and Vera Rajicic ${ }^{2}$
}

\author{
'University of Pristina-Kosovska Mitrovica, Faculty of Agriculture, Kopaonicka bb, 38228 Lesak, Serbia. \\ "Corresponding author (mbiberdzic@gmail.com). \\ ${ }^{2}$ Center for Crop Science, Save Kovacevica 31, 34000 Kragujevac, Serbia.
}

Received: 23 August 2019; Accepted: 30 November 2019; doi:10.4067/S0718-58392020000100080

\begin{abstract}
Tillage systems can affect soil compaction, water content, soil temperature, and yields of cultivated plants. This work examined a Vertisol and the influence of the tillage system on soil compaction and yield of winter wheat (Triticum aestivum L.) grains. The trial was conducted in the vicinity of Požega, Western Serbia, from 2014 to 2017. Four tillage systems (conventional tillage, reduced tillage, disc harrowing, and no-tillage) were applied in the experiment. Tillage systems have significantly influenced soil compaction, measurement time, and soil depth. Mean soil compaction in 20162017 was $1.96 \mathrm{MPa}$, which was 0.17 MPa lower than in 2014-2015 and 0.30 MPa higher than in 2015-2016. The highest mean wheat yield occurred in the conventional tillage system $\left(4033 \mathrm{~kg} \mathrm{ha}^{-1}\right)$, and it was significantly higher than the yield obtained in other soil tillage systems. There was a strong negative correlation between mean wheat yield and soil compaction. It was necessary to apply complete soil tillage to achieve satisfactory wheat grain yields on the Vertisol, which implies plowing and adequate pre-sowing soil preparation.
\end{abstract}

Key words: Conventional tillage, no-tillage, reduced tillage, Triticum aestivum.

\section{INTRODUCTION}

Tillage systems can affect soil filtration, water content, and soil temperature; they can significantly modify the physical, chemical, and biological properties of the soil. Küstermann et al. (2013) examined the effects of a conventional and reduced treatment with different $\mathrm{N}$ rates on wheat (Triticum aestivum $\mathrm{L}$.) yield in a crop rotation with potatoes; they collected data that indicated that conventional tillage (CT) at low and medium $\mathrm{N}$ rates produced higher wheat yields than (RT). These significantly higher wheat yields achieved in the CT system compared with RT are reported by Shahzad et al. (2016).

Moraru and Rusu (2012) examined the influence of CT, RT, and sowing with no-tillage (NT) and suggest that differences in wheat yield with these systems are nonsignificant. Khorami et al.(2018) examined the effects of CT and RT and sowing with NT on several wheat genotypes and concluded that the highest yields were achieved in the RT system, followed by the CT system, while the lowest yields occurred in the NT system.

There are contradictory data on crop yields in the RT and CT systems. Claassen (2012) considers that tillage with no plowing reduced erosion by more than one-third of arable land in the USA. Pittelkow et al. (2015) point out that the tillage systems must be adequately assessed economically and ecologically and indicate that NT systems in the dry regions of Africa increase yields compared with CT.

Analyzing the effect of CT and the NT system with wheat straw mulching on the yield of winter wheat in the dry regions of north-western China, Huang et al. (2012) mention that the NT system with wheat straw mulch increased mean 
wheat yield by $15.6 \%$ to $16.8 \%$ compared with CT. Copec et al. (2015) studied the influence of soil tillage systems on soil water content and yields of wheat and maize and concluded that the highest yield was achieved in the direct sowing system, which also had the highest water content. They point out that soil water content is positively correlated with wheat yield and is one of the decisive factors of plant production. In addition, Acar et al. (2017) studied similar problems under Mediterranean climate conditions and indicated that the differences in wheat grain yields among tillage systems were not significant, while the highest soil water content was achieved in conservation tillage and NT systems.

Soil compaction is one of the main forms of degradation. Mueller et al. (2010) state that compaction is a physical form of soil degradation that changes the soil structure and results in lower soil productivity. Pansak et al. (2008) and Govaerts et al. (2009) indicate that conventional soil cultivation best preserves soil moisture because crop residues are retained in the soil, evaporation is lower, and infiltration is higher.

Botta et al. (2010) point out that plant yields are reduced after several years of applying the NT system. This could be due to gradual soil compaction as a result of passages with heavy tractor seeders and harvesters, especially if these operations are carried out on moist soil.

Martinez et al. (2011) examined the impact of NT systems, NT systems and their procedures, and CT on soil compaction and wheat yield, and they conclude that the NT system combined with chisel plowing showed less soil compaction, especially at depths greater than $10 \mathrm{~cm}$ compared with other processing systems. The highest compaction was recorded in the NT system.

Hartmann et al. (2012) point out that droughts, as well as extreme highly intense rainfall, are important risk factors for soil compaction. Sang et al. (2016) indicate that long-term RT results in the formation of a watertight layer that prevents the infiltration of precipitation, which in turn results in lower wheat growth and lower yields. Barut and Celik (2017) showed that soil compaction in the CT system was 1.26 to $1.32 \mathrm{~g} \mathrm{~cm}^{-3}$ at all depths and was lower than in conservation tillage and sowing with NT. Organic matter content, water content, texture, and structure are the four essential factors determining the degree of soil compaction. Soil compaction has a direct effect on these factors which can impair physical and mechanical soil properties and create unfavorable conditions for plant growth and development (Nawaz et al., 2013).

Overall, soil compaction leads to a slowdown in the absorption of water and nutrients, weaker development of the root system as to length and penetration into the deeper layers, slow plant growth, which result in weaker plant growth and yield reduction (Nosalewicz and Lipiec, 2014; Prakash et al., 2014; D’Or and Destain, 2016). Therefore, the aim was to examine a Vertisol and the influence of tillage systems on soil compaction and yield of winter wheat grains.

\section{MATERIALS AND METHODS}

\section{Description of study areas}

The trial was conducted in the vicinity of Pozega, Western Serbia, during 2014-2015, 2015-2016, and 2016-2017 on a Vertisol. Pozega is located in southwest Serbia $\left(43^{\circ} 50^{\prime} 28^{\prime \prime}\right.$ N, $20^{\circ} 02^{\prime} 17 "$ E; 310 to 900 m.a.s.l.)

\section{Treatments and experimental design}

The experiment included the four soil tillage systems of conventional tillage (CT): autumn plowing + disc-harrowing + seedbed preparation, reduced tillage (RT): disc harrowing + seedbed preparation, disc harrowing (RT1), and no-tillage (NT). The wheat (Triticum aestivum L.) 'Pobeda' was planted. The trial design was the block system with four replicates. Sowing in each season was carried out at the end of October. Since wheat was cultivated in a crop rotation with maize (Zea mays L.), the harvest residues were removed immediately after the maize harvest. In the CT variant, basic tillage was conducted with a plow at a $25 \mathrm{~cm}$ depth, and the pre-sowing preparation was done at the $15 \mathrm{~cm}$ soil depth. In the RT treatment, disc harrowing was applied to a $15 \mathrm{~cm}$ depth, followed by pre-sowing seedbed preparation. In the RT1 treatment, soil was prepared with a disc harrow at a $15 \mathrm{~cm}$ depth. Before sowing to control weeds and make sowing easier in the NT treatment, $3 \mathrm{~L} \mathrm{ha}^{-1}$ total herbicide glyphosate (2-[phosphonomethylamino] acetic acid; Glifosav 480, Chemical Agrosava, Belgrade, Serbia) was used. Mineral nutrition involved applying $300 \mathrm{~kg} \mathrm{ha}^{-1} \mathrm{NPK}$ fertilizer (15:15:15) before sowing and $200 \mathrm{~kg} \mathrm{ha}^{-1}$ calcium ammonium nitrate (CAN) fertilizer for all varieties. Weed treatment was carried out in April with the herbicide metsulfuron-methyl (methyl 2-[\{4-methoxy-6-methyl-1,3,5-triazin-2-yl\}carbamoylsulfamoyl] benzoate; Metmark WP, Agromarket, Belgrade, Serbia) at $0.01 \%$. 
Plot size to measure soil compaction was $70 \mathrm{~m}^{2}$ with four replicates. Mean moisture content was also measured. Compaction was measured after sowing (AS) and before harvesting (BH) of wheat to a $40 \mathrm{~cm}$ depth with the Penetrologger Eijkelkamp, version 6.0 software (Eijkelkamp, Giesbeek, Netherlands). Compaction was measured according to the NEN 5140 standard (Royal Netherlands Standardization Institute, Delft, Netherlands), $2 \mathrm{~cm} \mathrm{~s}^{-1}$ penetration rate with a deviation of no more than $0.5 \mathrm{~cm} \mathrm{~s}^{-1}$, and all according to the standard soil cone penetrometer (ASAE S313.3; ASAE Standards, 2002). Compaction results were graphically illustrated for each year. Harvest occurred at full maturity in the first half of July.

\section{Statistical analysis}

Yield was calculated in each plot and adjusted to $14 \%$ grain moisture content. The dependence between yield and soil compaction was determined by Pearson's correlation coefficient. Results were processed statistically by ANOVA using the WASP, version 1.0 software (Indian Council of Agricultural Research [ICAR]-Central Coastal Agricultural Research Institute [CCARI], Ela, Goa, India). Individual comparisons were determined by the LSD test.

\section{Soil and climatic conditions}

Tables 1 and 2 show the soil chemical properties and the climatic characteristics of the area, respectively. The hydrolytic acidity of the soil was determined by Ca acetate extraction by Kappen's method. Humus was determined by the Kotzman method, total $\mathrm{N}$ by the Kjeldahl method, and available $\mathrm{P}$ and $\mathrm{K}$ by the Egner-Riehm (A-L) method.

The $\mathrm{pH}$ value of the soil solution for $\mathrm{KCl}$ in the $0-30 \mathrm{~cm}$ layer was 5.80 ; this soil belongs to a group of moderately acidic soils. According to the humus content (3.1\%), this soil belongs to a group of well-supplied soil. The $\mathrm{N}$ content

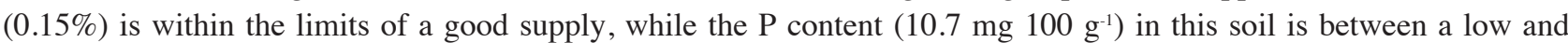
medium supply. According to the $\mathrm{K}$ content $\left(20 \mathrm{mg} 100 \mathrm{~g}^{-1}\right)$, this soil belongs to a group of an ideally supplied soil. In this type of soil, with proper agrotechnical and pedomeliorative measures (liming), plant production can be very successful.

This soil belongs to the class of clay soils that are suitable for cultivation for a short period of time and have a heavy texture (Golubovic et al., 2011). Full tillage is required on such soils to create a favorable water-air regime for plant growth and thus obtain higher yields.

Table 1. Soil chemical properties.

\begin{tabular}{|c|c|c|c|c|c|c|}
\hline \multirow[b]{2}{*}{ Depth } & & & \multirow[b]{2}{*}{ Humus } & \multicolumn{3}{|c|}{ Available nutrients } \\
\hline & \multicolumn{2}{|c|}{$\mathrm{pH}$} & & $\mathrm{N}$ & $\mathrm{P}_{2} \mathrm{O}_{5}$ & $\mathrm{~K}_{2} \mathrm{O}$ \\
\hline $\mathrm{cm}$ & $\mathrm{H}_{2} \mathrm{O}$ & $\mathrm{KCl}$ & $\%$ & $\%$ & $-\mathrm{mg}$ & $\mathrm{g}^{-1}-$ \\
\hline $0-30$ & 7.2 & 5.80 & 3.1 & 0.15 & 10.7 & 20.0 \\
\hline
\end{tabular}

Table 2. Climatic conditions in Požega, Western Serbia, from 2014 to 2017.

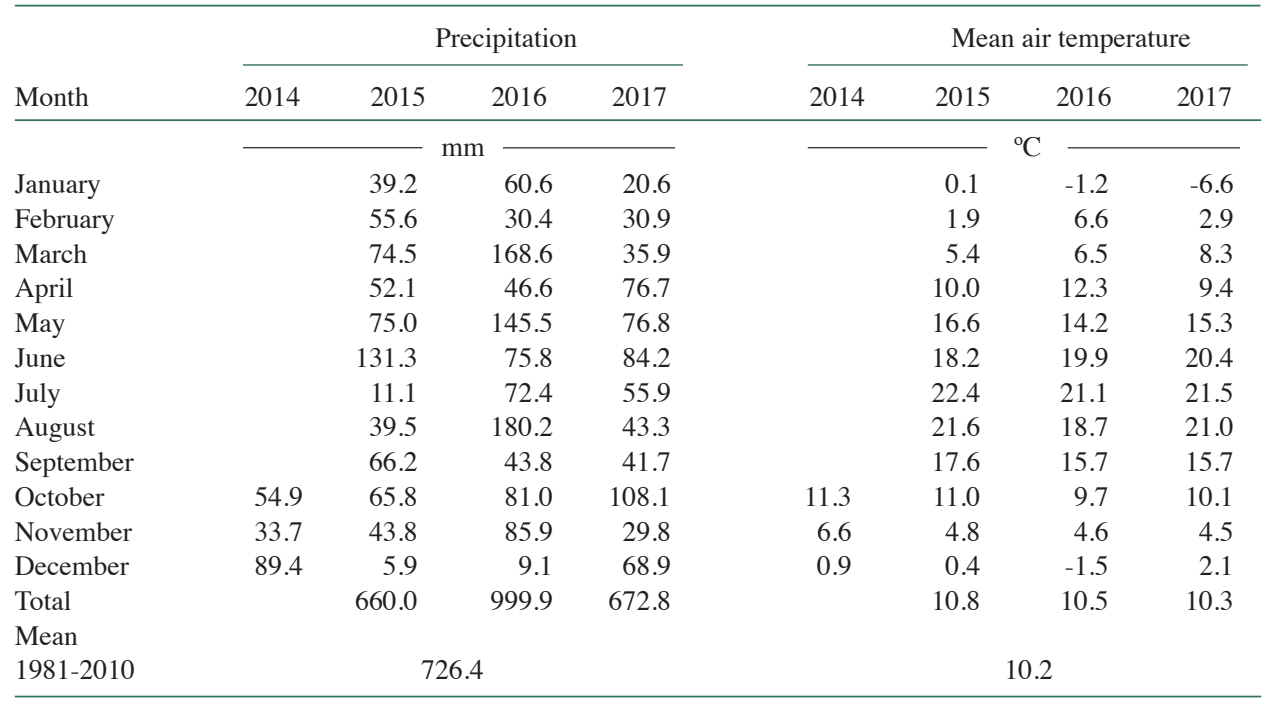


During the 2014-2015 (October-June) growing season, precipitation was 605.5, which was fairly regular. In the spring months (March, April, and May), total rainfall was $201.6 \mathrm{~mm}$, which was very important for the growth, flowering, and pollination of plants. Total precipitation in 2015 was $66.4 \mathrm{~mm}$ less compared with the historical mean. Temperature in this growing season was not a limiting factor. The mean annual temperature was $10.8{ }^{\circ} \mathrm{C}$, slightly higher than the historical mean.

During the 2015-2016 (October-June) growing season, precipitation was $643.0 \mathrm{~mm}$, which was $37.3 \mathrm{~mm}$ less than in the previous year. Rainfall was quite regular so that there was enough precipitation before and AS, which enabled timely tillage and good emergence. This season was characterized by a large amount of precipitation $(999.9 \mathrm{~mm})$, which was $273.5 \mathrm{~mm}$ higher than the historical mean. The large amount of rainfall and good rainfall schedule in this year had a positive influence on wheat yield, Temperature in this growing season was not a limiting factor. The mean annual temperature was $10.5^{\circ} \mathrm{C}$, slightly lower than in the previous year and slightly higher than the annual mean.

During the 2016-2017 (October-June) growing season, total rainfall was $501.1 \mathrm{~mm}$, which is $141.1 \mathrm{~mm}$ and $104.6 \mathrm{~mm}$ less than in the previous two seasons, respectively. The rainfall schedule was quite regular, so there was enough rainfall before and AS, which enabled timely tillage and sowing, as well as good sprouting. This season was characterized by $672.8 \mathrm{~mm}$ total rainfall, which was $327.1 \mathrm{~mm}$ less than in the previous year and at the level of total precipitation in 2015 . Mean temperature in this year was $10.3^{\circ} \mathrm{C}$, slightly lower than in previous years but within the range of the historical mean. This year was characterized by a colder winter compared with the previous $2 \mathrm{yr}$ and the mean monthly temperature was $-1.5^{\circ} \mathrm{C}$ in December and $-6.6^{\circ} \mathrm{C}$ in January; this represented no risk of freezing for the crops.

In terms of total precipitation and its distribution during crop growth and temperature conditions, the 2015-2016 growing season can be distinguished as the most suitable for wheat.

\section{RESULTS AND DISCUSSION}

\section{Soil compaction}

Soil compaction in all seasons was significantly influenced by the tillage system, measurement time, and depth. Figure 1 shows soil compaction for 2014-2015 as related to the tillage system, measurement time, and soil depth.

Mean soil compaction in 2014-2015 was 2.13 MPa. The highest mean soil compaction (2.47 MPa) was measured in NT and was significantly higher than in RT and CT. Nonsignificant differences were found between the RT and RT1 systems and the RT1 and CT systems for mean soil compaction. Mean soil compaction values BH were significantly higher than those AS. Mean soil compaction increased with increasing measurement depth from $1.37 \mathrm{MPa}(0-10 \mathrm{~cm})$ to $2.80 \mathrm{MPa}(30-40 \mathrm{~cm})$ and these differences were significant. The tillage system $(\mathrm{A}) \times$ Measurement time $(\mathrm{B})$ interaction showed very significant differences in all soil tillage systems. The $\mathrm{A} \times$ Soil depth $(\mathrm{C})$ interaction was the most expressed in all tillage systems between the 0-10 and 10-20 cm depths and differences were significant, while differences between

Figure 1. Influence of tillage system, measurement time, and depth on soil compaction in 2014-2015.

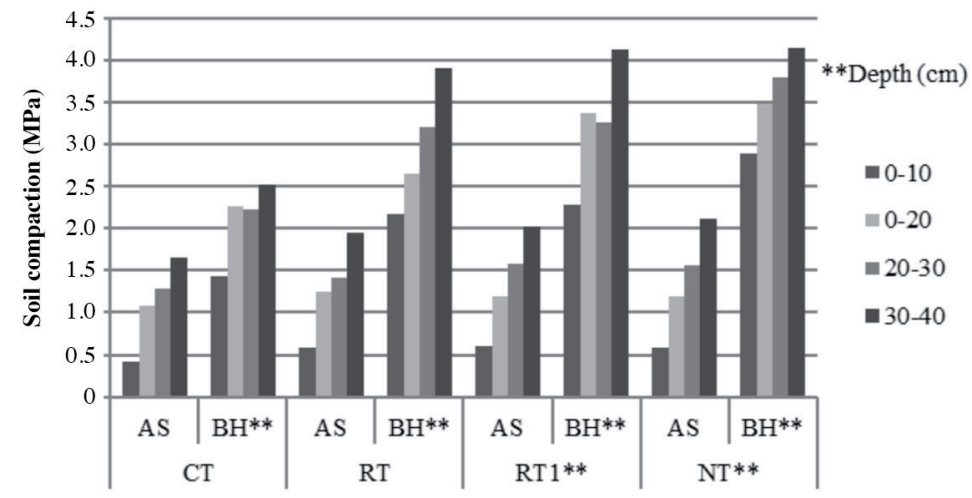

CT: Conventional tillage; R: reduced tillage; RT1: disc harrowing; NT: no-tillage; AS: after sowing; BH: before harvesting. **Significant at $p \leq 0.01$. 
the 10-20 and 20-30 cm depths were nonsignificant. The differences in soil compaction between $20-30$ and $30-40 \mathrm{~cm}$ in RT and RT1 were very significant, while differences in CT and NT were significant. The B $\times$ C interaction showed very significant differences; therefore, the lowest mean compaction for all the processing systems $(0.55 \mathrm{MPa})$ was measured at $0-10 \mathrm{~cm}$ after wheat sowing and the highest $(3.67 \mathrm{MPa}$ ) at $30-40 \mathrm{~cm}$ before wheat harvest. The $\mathrm{A} \times \mathrm{B} \times \mathrm{C}$ interaction showed very significant differences. The lowest soil compaction $(0.42 \mathrm{MPa})$ was measured in the CT system at $0-10 \mathrm{~cm}$ AS and the highest (4.14 MPa) was for the NT system at 30-40 cm BH.

Figure 2 shows soil compaction for 2015-2016 according to the tillage system, measurement time, and depth. Mean soil compaction in 2015-2016 was 1.66 MPa, which was 0.47 MPa lower than in the previous year. The highest mean soil compaction value (1.87 MPa) was measured in the NT system and was significantly higher than other tillage systems, which showed nonsignificant differences. Mean soil compaction values measured $\mathrm{BH}$ were significantly higher than those measured AS. Mean soil compaction increased as depth increased from 0.99 MPa $(0-10 \mathrm{~cm})$ to $2.02 \mathrm{MPa}(30-40$ $\mathrm{cm}$ ); these differences were therefore significant. The $\mathrm{A} \times \mathrm{B}$ interaction showed very significant differences in all tillage systems, except RT. The A $\times$ C interaction in all tillage systems was expressed the most between 0-10 and 10-20 cm and these differences were significant, while the differences between 10-20, 20-30, and 30-40 cm in the RT system, RT1, and $\mathrm{NT}$ were nonsignificant. The $\mathrm{B} \times \mathrm{C}$ interaction showed very significant differences, so the lowest mean compaction for all tillage systems $(0.54 \mathrm{MPa})$ was measured at $0-10 \mathrm{~cm}$ AS and the highest $(3.67 \mathrm{MPa})$ at $30-40 \mathrm{~cm} \mathrm{BH}$. The $\mathrm{A} \times \mathrm{B} \times \mathrm{C}$ interaction showed very significant differences. The lowest soil compaction $(0.45 \mathrm{MPa})$ was measured in the CT system at $0-10 \mathrm{~cm}$ AS, and the highest (3.11 MPa) was in the NT system at 30-40 cm BH. Lower mean compaction and smaller differences for the soil depth profile in this year compared with the previous year were caused by higher precipitation and its distribution.

Figure 3 shows soil compaction in 2016-2017 according to the tillage system, measurement time, and depth. Mean soil compaction in 2016-2017 was 1.96 MPa, which was 0.17 MPa lower than in 2014-2015 and 0.30 MPa higher than in 2015-2016. The highest mean soil compaction (2.22 MPa) was measured in NT and was significantly higher than other tillage systems. The RT and RT1 systems, in which nonsignificant differences were found, had significantly higher compaction than CT. Mean soil compaction values measured BH were significantly higher than those measured AS. Mean soil compaction for all tillage systems significantly increased up to a depth of $20-30 \mathrm{~cm}$, so that the differences in soil compaction between 20-30 and 30-40 cm were at the limit of statistical significance. The $\mathrm{A} \times \mathrm{B}$ interaction showed very significant differences in all tillage systems. The $\mathrm{A} \times \mathrm{C}$ interaction in all processing systems was the most expressed up to $30 \mathrm{~cm}$ and these differences were very significant. In the CT, RT, and NT treatments, differences in compaction between 20-30 and 30-40 cm were nonsignificant. The $\mathrm{B} \times \mathrm{C}$ interaction showed very significant differences, so that the lowest mean compaction for all tillage systems $(0.56 \mathrm{MPa})$ was measured at $0-10 \mathrm{~cm}$ AS and the highest $(3.12 \mathrm{MPa})$ at $30-40 \mathrm{~cm}$ $\mathrm{BH}$. The $\mathrm{A} \times \mathrm{B} \times \mathrm{C}$ interaction showed very significant differences. The lowest soil compaction $(0.52 \mathrm{MPa})$ was measured in the CT system at 0-10 $\mathrm{cm} \mathrm{AS}$, and the highest (3.61 MPa) in the NT system at $30-40 \mathrm{~cm} \mathrm{BH}$.

Figure 2. Influence of system tillage, measurement time, and depth on soil compaction in 2015-2016.

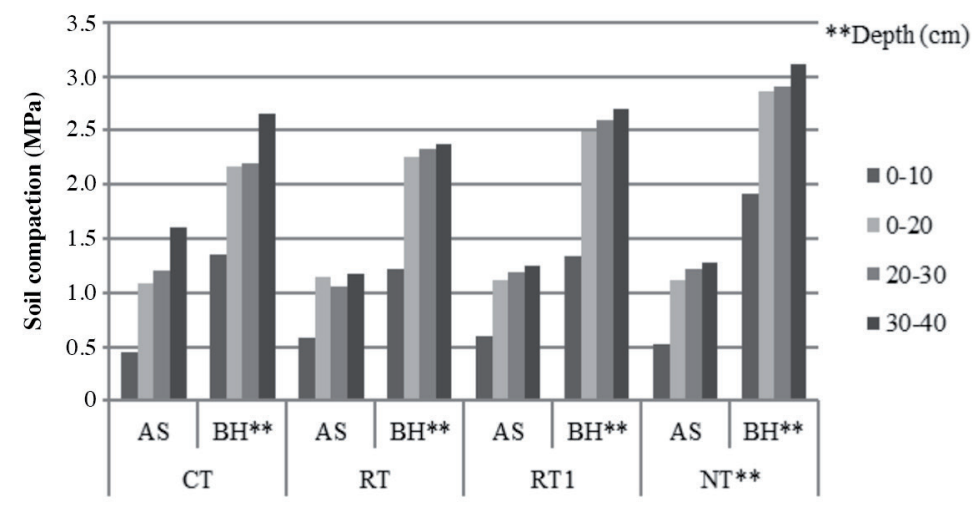

CT: Conventional tillage; R: reduced tillage; RT1: disc harrowing; NT: no-tillage; AS: after sowing; BH: before harvesting. ** Significant at $p \leq 0.01$. 
Figure 3. Influence of system tillage, measurement time, and depth on soil compaction in 2016-2017.

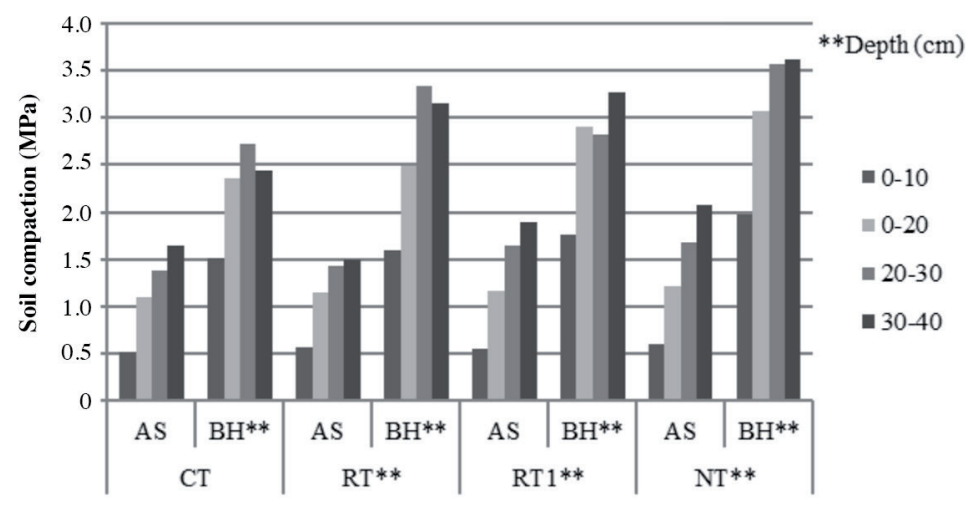

CT: Conventional tillage; R: reduced tillage; RT1: disc harrowing; NT: no-tillage; AS: after sowing; BH: before harvesting. $* *$ Significant at $p \leq 0.01$.

In every year of the 3-yr study, the highest values of soil compaction at $40 \mathrm{~cm}$ were determined for the NT system compared with other tillage systems. In every year, tillage systems, measuring time, and soil depth had a very significant impact on soil compaction. These results concur with the findings by Rusu et al. (2011), who highlight significantly higher values of soil compaction in wheat at depths of up to $45 \mathrm{~cm}$ in the NT system, and nonsignificant differences in other systems. Tolon-Becerra et al. (2011) measured soil compaction based on depth and number of tractor passages and pointed out a significant increase in soil compaction when depth increased to $60 \mathrm{~cm}$. Similar results were obtained by Hernández et al. (2019). Our results concur with the findings by Bogunovic et al. (2014), who indicated that the tillage system has a significant influence on soil compaction in all profiles up to $60 \mathrm{~cm}$, except in months with the highest precipitation. The same authors mention that the highest compaction was in the NT and minimal tillage systems, and the lowest was in the CT system. The specificity of our research is that it was carried out on soils of the Vertisol type, which is a type of heavy mechanical composition and very specific for cultivation. If this is compounded by the fact that the soil is not fertilized with organic fertilizers, but only with mineral fertilizers, and retains moisture in deeper layers, this creates conditions for this soil that is not cultivated or minimally cultivated, especially in the arable layer, to have higher compaction. Thus, Nawaz et al. (2013) point out that clay soils under lower moisture content are more susceptible to compaction than those with a sandy texture.

The highest soil compaction was recorded in the NT system because there was no tillage and some of the procedures of NT systems practiced in other countries were not used.

\section{Soil moisture}

Soil moisture is an important indicator of successful crop production; it was determined when measuring soil compaction and is expressed as mean values at a 0-40 cm depth. Table 3 gives an overview of soil moisture content according to tillage system, measurement time, and year of study.

Soil moisture content was significantly influenced by measurement time and years under study. However, nonsignificant differences were found between tillage systems for mean moisture content, which concurs with the results found by Blanco-Canqui et al. (2017). Mean moisture content for all tillage systems and years under study was $23.3 \%$ AS and $22.6 \%$ $\mathrm{BH}$; these differences are very significant. The highest mean moisture content for all tillage systems and measurement times was in 2015-2016 (23.6\%), and it was significantly higher than in the other $2 \mathrm{yr}$. It should be noted that the highest soil moisture content of all tillage systems was in 2015-2016 when the highest rainfall occurred during wheat growth and which had a positive effect on wheat yield. Our results are in line with the results reported by Pansak et al. (2008), who indicate that soil moisture is best stored in a CT system. However, our results do not concur with Martinez et al. (2011), who highlight the highest soil moisture values at depths of up to $50 \mathrm{~cm}$ in NT systems. 
Table 3. Influence of tillage systems, measurement time, and year on soil moisture (\%).

\begin{tabular}{|c|c|c|c|c|c|c|c|c|}
\hline \multirow{2}{*}{$\begin{array}{l}\text { Tillage } \\
\text { systems (A) }\end{array}$} & & \multirow{2}{*}{$\begin{array}{l}\text { Moisture } \\
\text { measurement } \\
\text { time (B) }\end{array}$} & \multicolumn{6}{|c|}{ Years (C) } \\
\hline & & & 2014-2015 & & $2015-2016$ & 2016-201 & & Mean AB \\
\hline \multirow[t]{3}{*}{ CT } & & AS & 23.1 & & 24.3 & 21.8 & & 23.1 \\
\hline & & $\mathrm{BH}$ & 21.3 & & 23.8 & 22.7 & & 22.6 \\
\hline & Mean AC & & 22.2 & & 24.1 & 22.3 & & 22.8 \\
\hline \multirow[t]{3}{*}{ RT } & & AS & 23.9 & & 25.0 & 21.4 & & 23.4 \\
\hline & & $\mathrm{BH}$ & 20.8 & & 21.7 & 21.5 & & 21.3 \\
\hline & Mean AC & & 22.3 & & 23.3 & 21.4 & & 22.3 \\
\hline \multirow[t]{3}{*}{ RT1 } & & AS & 24.7 & & 25.5 & 20.7 & & 23.6 \\
\hline & & $\mathrm{BH}$ & 21.1 & & 23.6 & 20.6 & & 21.7 \\
\hline & Mean AC & & 22.9 & & 24.5 & 20.6 & & 22.7 \\
\hline \multirow[t]{3}{*}{ NT } & & AS & 23.8 & & 24.2 & 21.6 & & 23.2 \\
\hline & & $\mathrm{BH}$ & 20.4 & & 21.2 & 22.2 & & 21.2 \\
\hline & Mean AC & & 22.1 & & 22.7 & 21.9 & & 22.2 \\
\hline \multirow[t]{3}{*}{ Mean BC } & & AS & 23.9 & & 24.7 & 21.2 & & 23.3 \\
\hline & & BH & 20.9 & & 25.6 & 21.4 & & 22.6 \\
\hline & Mean C & & 22.4 & & 23.6 & 21.5 & & 22.6 \\
\hline \multirow[t]{4}{*}{ LSD } & Level & A & B & $\mathrm{C}$ & $A \times B$ & $\mathrm{~A} \times \mathrm{C}$ & $\mathrm{B} \times \mathrm{C}$ & $\mathrm{A} \times \mathrm{B} \times \mathrm{C}$ \\
\hline & $F$ test & $923.84^{\text {ns }}$ & $217.27 * *$ & $56.73^{* *}$ & $* \quad 217.27 * *$ & $56.73^{* *}$ & $65.98 * *$ & $65.98 * *$ \\
\hline & 0.05 & 0.71 & 0.50 & 0.61 & 1.00 & 1.23 & 0.87 & 1.74 \\
\hline & 0.01 & 0.95 & 0.67 & 0.82 & 1.34 & 1.64 & 1.16 & 2.32 \\
\hline
\end{tabular}

CT: Conventional tillage; RT: reduced tillage; RT1: disc harrowing; NT: no-tillage; AS: after sowing; BH: before harvesting; ${ }^{\text {ns: }}$ nonsignificant.

$* *$ Significant at $p \leq 0.01$.

\section{Wheat yield}

Wheat yield is conditioned by numerous factors, especially agrotechnical, agro-climatic, and genetic. Table 4 shows the yield of winter wheat according to the tillage system and year of study.

Wheat yield significantly depended on both the year and tillage system. The highest 3-yr wheat yield was achieved in the CT system (4033 $\mathrm{kg} \mathrm{ha}^{-1}$ ), and it was significantly higher than yield obtained in the NT system, and in RT and RT1 systems. There was nonsignificant difference in wheat yield between the RT and RT1 systems. The highest mean wheat yield for all tillage systems was in 2015-2016 (3744 $\left.\mathrm{kg} \mathrm{ha}^{-1}\right)$, and it was significantly higher than yield in 2014-2015. Nonsignificant differences were found between mean yields in 2014-2015 and 2016-2017. The lowest yield (2680 kg ha-1) was in the NT system in 2014-2015, and the highest (4280 $\left.\mathrm{kg} \mathrm{ha}^{-1}\right)$ in the CT system in 2015-2016. Mean yield in the CT system was from $12.43 \%$ to $29.51 \%$ higher than yield in RT and NT systems.

The highest wheat yield was in the CT system in 2015-2016 when there was also the highest rainfall, the highest soil moisture, and the lowest compaction. Our results concur with the results reported by Shahzad et al. (2016), who obtained

Table 4. Influence of tillage system on winter wheat yield.

\begin{tabular}{|c|c|c|c|c|c|}
\hline \multirow[b]{2}{*}{ Tillage systems (factor A) } & \multicolumn{3}{|c|}{ Years (factor B) } & \multirow[b]{2}{*}{ Mean of factor $\mathrm{A}$} & \multirow[b]{3}{*}{$\%$} \\
\hline & 2014-2015 & 2015-2016 & 2016-2017 & & \\
\hline & 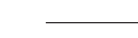 & - $\mathrm{kg} \mathrm{ha}^{-1}$ & - & $\mathrm{kg} \mathrm{ha}^{-1}$ & \\
\hline $\mathrm{CT}$ & 3890 & 4280 & 3930 & 4033 & 100.00 \\
\hline RT & 3410 & 3790 & 3410 & 3536 & 87.67 \\
\hline RT1 & 3370 & 3768 & 3460 & 3532 & 87.57 \\
\hline NT & 2680 & 3140 & 2710 & 2843 & 70.49 \\
\hline \multirow[t]{2}{*}{ Mean of factor B } & 3337 & 3744 & 3377 & 3486 & \\
\hline & & $\mathrm{A}$ & B & $\mathrm{A} \times \mathrm{B}$ & \\
\hline \multirow[t]{3}{*}{ LSD } & F test & $24.929 * *$ & $12.950 *$ & $12.950 * *$ & \\
\hline & 0.05 & 451.33 & 390.86 & 701.73 & \\
\hline & 0.01 & 613.45 & 531.26 & 1062.53 & \\
\hline
\end{tabular}

CT: Conventional tillage; RT: reduced tillage; RT1: disc harrowing; NT: no-tillage. $* *$ Significant at $p \leq 0.01$. 
higher wheat grain yields of $9.8 \%$ to $19.2 \%$ in the CT system compared with RT and NT. Dai et al. (2013) mention lower wheat yields in the NT system by $6 \%$ compared with CT systems; our results are consistent with these authors. Wozniak (2013) also indicated significantly higher wheat grain yields in the CT system compared with the RT and NT systems. A decrease in grain yield after direct sowing between $8 \%$ and $33 \%$ can be caused by higher soil compaction in the 15-25 $\mathrm{cm}$ depth layer (Rátonyi et al., 2005). Martinez et al. (2011) emphasize that in the favorable productive years, wheat yield was the highest in the CT compared with conservation tillage and NT systems.

Our results do not concur with the results found by Moraru and Rusu (2012), who point out that there are nonsignificant differences in wheat yields among soil treatment systems. Huang et al. (2012) mentioned significantly higher wheat yields in the NT than CT system.

Plant yield strongly depends on the soil conditions in which the root system develops. The quality of soil conditions is defined by the favorable water-air regime, mechanical composition, and supply of soil nutrients. These conditions, especially in soils with heavy mechanical composition as in our case, can be achieved by quality and timely treatment and use of organic fertilizers. Only under such conditions is it possible to expect high yields of cultivated plants on these soil types. If this soil is not being tilled or is being minimally tilled, conditions for higher compaction and poor soil conditions are being created; this is reflected in lower yields of cultivated plants, which is evident in our research.

\section{Correlation}

Figure 4 shows the correlation between yield, soil moisture, and soil compaction. Water content in the soil is an indicator of water availability in the plant and an indicator of lower soil compaction; crop yield depends on these factors. In our 3-yr study, a mean positive correlation was found between soil yield and water content, as shown by Pearson's coefficient, $\mathrm{r}=$ 0.49. Vrindts et al. (2005) state that in areas with higher soil moisture variability, grain yields decrease.

Mean wheat yield had a strong negative correlation with soil compaction in which the coefficient of correlation was $r=-0.85$. Ramazan et al. (2012) point out that wheat yield decreases when soil compaction increases, which is consistent with our results.

Figure 4. Correlation between yield, soil moisture, and soil compaction.
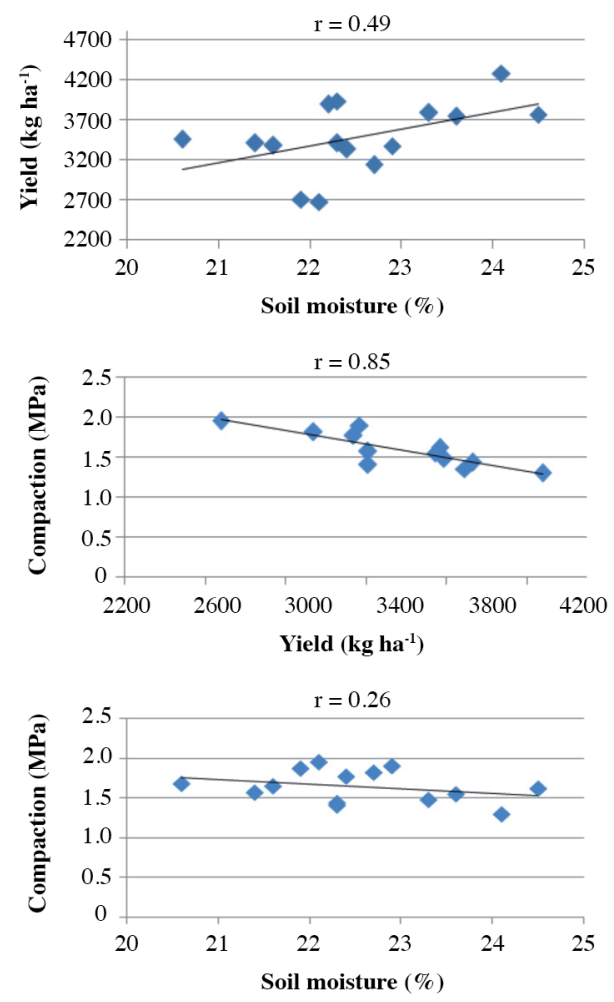
The higher the soil moisture content, the lower the solid phase content, and thus less soil compaction. For higher wheat yields, lower compaction and higher water content are desirable. A weak negative correlation was found between these two properties, as shown by Pearson's coefficient, $r=-0.26$. The study by Nyéki et al. (2017) showed that changes in soil moisture content had the opposite effect on the natural compaction of clay, which is reflected in the wheat yield.

\section{CONCLUSIONS}

Tillage systems, measurement time, and soil depth had a significant impact on soil compaction. The highest soil compaction was recorded in the no-tillage (NT) system because there was no tillage and some of the procedures of NT systems practiced in other countries were not used. Soil compaction in all tillage systems measured after sowing the wheat was significantly lower than when measured before harvesting. Soil compaction increased as depth increased, reaching the highest value at $30-40 \mathrm{~cm}$. Soil moisture content was significantly influenced by measurement time and year of study. However, nonsignificant differences were found between the tillage systems and mean moisture content.

Wheat yield significantly depended on year and tillage system. The highest 3 -yr wheat yield occurred in the conventional tillage (CT) system, and it was significantly higher than yields achieved in other tillage systems. The highest wheat yield was in 2015-2016 in the CT system when there was also the highest rainfall, the highest soil moisture content, and the lowest compaction. A mean positive correlation was found between yield and soil moisture, a strong negative correlation between yield and soil compaction, and a weak negative correlation between soil moisture and soil compaction. If this soil is not being tilled or is being minimally tilled, conditions for higher compaction and poor soil conditions are being created; this is reflected in lower yields of cultivated plants, which is evident in our study.

Full tillage, including plowing and adequate pre-sowing soil preparation, is necessary to achieve satisfactory yields of wheat grown on a Vertisol.

\section{ACKNOWLEDGEMENTS}

This study was supported by the Ministry of Education, Science and Technological Development of the Republic of Serbia, project Nr TR 31054 and project Nr TR 31051.

\section{REFERENCES}

Acar, M., Celik, I., and Günal, H. 2017. Effects of long-term tillage systems on soil water content and wheat yield under Mediterranean conditions. Journal of New Theory 17:98-108.

ASAE Standards. 2002. S313.3. Soil cone penetrometer. $49^{\text {th }}$ ed. American Society of Agricultural Engineers (ASAE), St. Joseph, Michigan, USA.

Barut, Z., and Celik, I. 2017. Tillage effects on some soil physical properties in a semi-arid Mediterranean region of Turkey. Chemical Engineering Transactions 58:217-222.

Blanco-Canqui, H., Wienhold, B.J., Jin, V.L., Schmer, M.R., and Kibet, L.C. 2017. Long-term tillage impact on soil hydraulic properties. Soil and Tillage Research 170: 8-42.

Bogunovic, I., Kisic, I., and Jurisic, J. 2014. Soil compaction under different tillage system on Stagnic Luvisol. Agriculturae Conspectus Scientificus 79(1):57-63.

Botta, G.F., Tolon-Becerra, A., Lastra-Bravo, X., and Tourn, M. 2010. Tillage and traffic effects (planters and tractors) on soil compaction and soybean (Glycine max L.) yields in Argentinean pampas. Soil and Tillage Research 110(1):167-17.

Claassen, R. 2012. The future of environmental compliance incentives in U.S. agriculture. The role of commodity, conservation, and crop insurance programs. Economic Information Bulletin Nr 94.94 p. Economic Research Service, USDA, Washington, DC, USA.

Copec, K., Filipovic, D., Husnjak, S., Kovacev, I., and Kosutic, S. 2015. Effects of tillage systems on soil water content and yield in maize and winter wheat production. Plant, Soil and Environment 61(5):213-219.

Dai, X., Li, Y., Ouyang, Z., Wang, H., and Wilson, G.V. 2013. Organic manure as an alternative to crop residues for no-tillage wheat-maize systems in North China Plain. Field Crops Research 149(1):141-148.

D'Or, D., and Destain, M.F. 2016. Risk assessment of soil compaction in the Walloon region in Belgium. Mathematical Geosciences 48:89-103.

Golubovic, S., Bacanovic, D., Knezevic, M., and Dordevic, A. 2011. Basic physical properties of vertisol of Pčinja district parameter control. Land and Plant 60(3):103-116. 
Govaerts, B., Sayre, K.D., Goudeseune, B., De Corte P., Lichter, K., Dendooven L., et al. 2009. Conservation agriculture as a sustainable option for the central Mexican highlands. Soil and Tillage Research 103:222-209.

Hartmann, P., Zink, A., Fleige, H., and Horn, R. 2012. Effect of compaction, tillage and climate change on soil water balance of Arable Luvisols in Northwest Germany. Soil and Tillage Research 124:211-218.

Hernández, D.B.T., Slater, K.B., Corbalá, T.R., and Shaffer, M.J. 2019. Assessment of long-term tillage practices on physical properties of two Ohio soils. Soil and Tillage Research 186:270-279.

Huang, G., Chai, Q., Feng, F., and Yu, A. 2012. Effects of different tillage systems on soil properties, root growth, grain yield, and water use efficiency of winter wheat (Triticum aestivum L.) in arid Northwest China. Journal of Integrative Agriculture 11(8):1286-1296.

Khorami, S.S., Kazemeini, S.A., Afzalinia, S., and Gathala, M.K. 2018. Changes in soil properties and productivity under different tillage practices and wheat genotypes: a short-term study in Iran. Sustainability 10:3273.

Küstermann, B., Munch, J.C., and Hülsbergen, K.J. 2013. Effects of soil tillage and fertilization on resource efficiency and greenhouse gas emissions in a long-term field experiment in Southern Germany. European Journal of Agronomy 49:61-73.

Martinez, I., Ovalle, C., Del Pozo, A., Uribe, H., Valderrama, N., Prat, C., et al. 2011. Influence of conservation tillage and soil water content on crop yield in dryland compacted Alfisol of central Chile. Chilean Journal of Agricultural Research 71:615-622.

Moraru, P.I., and Rusu, T. 2012. Effect of tillage systems on soil moisture, soil temperature, soil respiration and production of wheat, maize and soybean crops. Journal of Food, Agriculture and Environment 10(2):445-448.

Mueller, L., Schindler, U., Mirschel, W., Shepherd, T.G., Ball, B.C., Helming, K., et al. 2010. Assessing the productivity function of soils. A review. Agronomy for Sustainable Development 30:601-614.

Nawaz, M.F., Bourrié, G., and Trolard, F. 2013. Soil compaction impact and modelling. A review. Agronomy for Sustainable Development 33:291-309.

Nyéki, A., Milics, G., Kovács, A.J., and Nemény, I.M. 2017. Effects of soil compaction on cereal yield. Cereal Research Communications 45(1):1-22.

Nosalewicz, A., and Lipiec, J. 2014. The effect of compacted soil layers on vertical root distribution and water uptake by wheat. Plant and Soil 375:229-240.

Pansak, W., Hilger, T.H., Dercon, G., Kongkaew, T., and Cadisch, G. 2008. Changes in the relationship between soil erosion and $\mathrm{N}$ loss pathways after establishing soil conservation systems in uplands of Northeast Thailand. Agriculture, Ecosystems and Environment 128:167-176.

Pittelkow, M.C., Linquist, A.B., Lundy, E.M., Liang, X., Groenigen, J., Lee, J., et al. 2015. When does no-till yield more? A global meta-analysis. Field Crops Research 183:156-168.

Prakash, K., Sridharan, A., and Prasanna, H.S. 2014. Compaction induced yield stress. Geotechnical Geological Engineering 32:311-319.

Ramazan, M., Daraz, G.K., Hanif, M., and Shahid, A. 2012. Impact of soil compaction on root length and yield of corn under irrigated condition. Middle-East Journal of Scientific Research 11(3):382-385.

Rátonyi, T., Huzsvai,L., Nagy, J., and Megyes, A. 2005. Evaluation of soil tillage systems in maize production. Acta Agronomica Hungarica 53:53-57.

Rusu, T., Moraru, P.I., Ranta, O., Drocas, I., Bogdan, I., Pop, A.I., et al. 2011. No-tillage and minimum tillage-their impact on soil compaction, water dynamics, soil temperature and production on wheat, maize and soybean crop. Bulletin of the University of Agricultural Sciences and Veterinary Medicine Cluj-Napoca Agriculture 68(1):318-323.

Sang, X., Wang, D., and Lin, X. 2016. Effects of tillage practices on water consumption characteristics and grain yield of winter wheat under different soil moisture conditions. Soil and Tillage Research 163:185-194.

Shahzad, M., Farooq, M., Jabran, K., Yasir, T.A., and Hussain, M. 2016. Influence of various tillage practices on soil physical properties and wheat performance in different wheat-based cropping systems. International Journal of Agriculture and Biology 18:821-829.

Tolon-Becerra, A., Lastra-Bravo, X.B., Botta, G.F., Tourn, M., Linares, P., Ressia, M., et al. 2011. Traffic effect on soil compaction and yields of wheat in Spain. Spanish Journal of Agricultural Research 9(2):395-403.

Vrindts, E., Mouazen, A.M., Reyniers, M., Maertens, K., Malek, M.R., Ramon, H., et al. 2005. Management zones based on correlation between soil compaction, yield and crop data. Biosystems Engineering 92(4):419-428.

Wozniak, A. 2013. The effect of tillage systems on yield and quality of durum wheat cultivars. Turkish Journal of Agriculture and Forestry 37:133-138. 